\title{
The effect of social capital on knowledge creation in Petrochemical Industry
}

\author{
Mohammad Reza Saadi $^{\mathbf{a}^{*}}$ and Narjes Pahlavani ${ }^{\mathbf{b}}$
}

\begin{abstract}
${ }^{a}$ Assistant Professor, Research Center of Economic Studies, Allameh Tabatabai University, Tehran, Iran
${ }^{b}$ Master Student, Department of Management, University of Tehran, Tehran, Iran,

C H R O N I C L E

Article history:

Received October 12, 2012

Received in revised format

26 January 2013

Accepted 27 January 2013

Available online

January 302013

Keywords:

Social capital

Cognitive capital

Relational capital

Structural capital

\section{A B S T R A C T}

Knowledge creation and innovation are primary competitive advantage in the modern economy. Social capital, on the other hand, is one the most important components of organizations, which could help share knowledge within organization and create competitive advantage. The purpose of this paper is to investigate the impact of social capital on knowledge creation in petrochemical industry. The survey designs a questionnaire and distributes it among some experts who worked for petrochemical industry. The study investigates the impact of social capital in terms of three components of cognitive, relational and structural capitals on knowledge creation. Cronbach alpha in combined form is calculated as 0.79 , which validates the overall survey. Structural equation modeling has been used to examine the proposed study and the results have confirmed that all three items positively influence knowledge creation, significantly.
\end{abstract}

\section{Introduction}

With the revolution in information technology and the rapid development of information and network technology, there has been a major change in the pattern of global economic growth since nineteenth and knowledge has become the most important assets as a replacement of financial and physical capital (Hansen, 1999; Chen et al., 2004). Knowledge-based business environment requires new organizational approach to include intangible assets such as knowledge and competence of human resources, innovation, customer relations, organizational culture, systems, organizational structure, etc. In such circumstances, social capital has become an interesting area of investigation (Bontis, 1995; Bontis, 1999). Social capital is one of the most important components of social capital, which could help organizations create success (Nahapiet \& Ghoshal, 1998). 
Some researchers have examined the impact of social capital on the transmission of other sources but, to the best of our knowledge, there is no research on relationship between social capital and knowledge creation. The organization is a social group, characterized by efficiency and speed in the transfer of knowledge (Kogut \& Zander, 1996) and it is new concept of organization theory (Nonaka \& Takeuchi, 1995; Zander \& Kogut, 1995). In addition, organizations must have inside organizational relationships to overcome to any unwanted uncertainties (Carey \& Lawson, 2011). Social capital is one the most important components of any organization, which could help deliver the necessary knowledge (Nahapiet \& Ghoshal, 1998; Wood et al., 2012).

The primary component of social capital is associated with different patterns of connection among employees (Burt, 1995). There are different types of relationships among members of an organization. For instance, Burt (1995) discusses that a limited number of people could build better connections with others and Hansen (1999) stated that a weak relationship is a major barrier for transferring knowledge. In fact, a suitable organization could build better connections with other firms. A good relationship is the primary source of learning and communicating with others (Chen \& $\mathrm{Wu}, 2010)$. There are normally two kinds of relationships of one way and two ways communications. In one-way relationship, the flow of information is distributed from one side while in two-way communication, people could get in touch with each other and there is a better method for communication (Prahinski \& Benton, 2004).

According to Mohr and Nevin (1990), in two-way communication, there is a better mutual trust and respect between people. The quality of information is another component of social relationship and helps people make good decisions (Oliver \& Anderson, 1995). According to Haghighat (2008), an organization with good technology equipment could improve itself for empowering employees. According to Lévy Mangin et al. (2008), information technology could facilitate information inside organizations. Relationship is another component of social capital, which includes different components including trust, normality, rules and regulations as well as expectations and identity (Nahapiet \& Ghoshal, 1998). Trust is the most influential component for building social capital (Boisot, 1995) followed by normality, which is an essential part of building trust (Starbuck, 1992). Expectation is another important component of building a stable social capital (Coleman, 1994). People in a social network must have unique identity and close believes (Cicourel, 1973).

\section{The proposed method}

The purpose of this paper is to investigate the impact of social capital on knowledge creation in petrochemical industry. The proposed study of this paper considers whether social capital has any impact on knowledge creation and how it influences on creating knowledge. The study investigates the impact of social capital in terms of three components of cognitive, relational and structural capitals on knowledge creation. Fig. 1 shows details of our survey

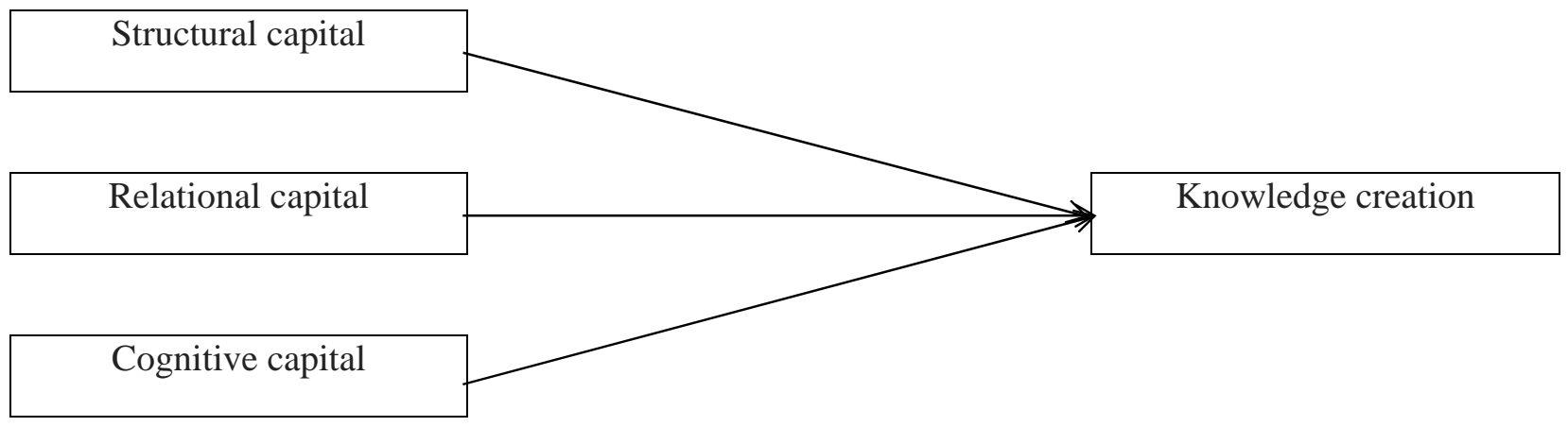

Fig. 1. The framework of the proposed model 
As we can observe from Fig. 1, there are three sub-hypothesis associated with the proposed study of this paper as follows,

1. Structural capital influence positively on knowledge creation.

2. Relational capital influence positively on knowledge creation.

3. Cognitive capital influence positively on knowledge creation.

The proposed study has been performed among 270 petro chemical experts who had sufficient experiences in this industry and the sample size is calculated as follows,

$n=\frac{N \times z_{\alpha / 2}^{2} \times p \times q}{\varepsilon^{2} \times(N-1)+z_{\alpha / 2}^{2} \times p \times q}$,

where $N$ is the population size, $p=1-q$ represents the yes/no categories, $z_{\alpha / 2}$ is CDF of normal distribution and finally $\varepsilon$ is the error term. Since we have $p=0.5, z_{\alpha / 2}=1.96$ and $N=290$, the number of sample size is calculated as $n=170$. We have distributed 170 questionnires and collected 118 filled ones. The proposed study designed the questionnaire in Likert scale and used 12 experts feedback to validate the questionnaire. Cronbach alphas were calculated for structural capital, relational capital and human capital as 0.768, 0.798 and 0.842, respectively. In addition, Cronbach alpha was calculated for knowledge creation as 0.810 and overal Cronbach was calculated as 0.79 , which is well above the minimum acceptable limit. We use structural equation modeling to study the impacts of different variables based on factor analysis.

\section{The results}

We first present details of important factors using first round of factor analysis on different decision variables.

\section{Table 1}

The results of factor analysis

\begin{tabular}{|c|c|c|c|}
\hline Variable & KMO and Bartlet test & Factor(Variance) & \% of variance \\
\hline Structrual & $\begin{array}{l}\mathrm{KMO}=0.743 \\
\text { Sig. }=0.000\end{array}$ & $\begin{array}{l}\text { Warm relationships (38.6), strong working relationship(24.7), } \\
\text { facilitating structure(18.3), Communication (27.8) }\end{array}$ & 80.9 \\
\hline Relational & $\begin{array}{l}\text { KMO=0.786, } \\
\text { Sig. }=0.000\end{array}$ & $\begin{array}{l}\text { Mutual trust relationships (30.7), Cooperation as a rule (18.9), } \\
\text { existance of team work (23.2), accepting criticisim (18.6), } \\
\text { Commitment to organization's interest (18.2), Being a member } \\
\text { of family organization (19.6) }\end{array}$ & 79.9 \\
\hline Cognitive & $\begin{array}{l}\text { KMO }=0.815 \\
\text { Sig. }=0.000\end{array}$ & $\begin{array}{l}\text { Existence of common objectives (43.7), Cooperation based on } \\
\text { common interest (24.8) }\end{array}$ & 71.64 \\
\hline $\begin{array}{l}\text { Knowledge } \\
\text { creation }\end{array}$ & $\begin{array}{l}\text { KMO=0.858, } \\
\text { Sig. }=0.000\end{array}$ & $\begin{array}{l}\text { Creating new opportunities by technology (12.3), Creating new } \\
\text { technologies (26.8), Differenation between various technologies } \\
\text { (26.2), Learning from technology (24.1) }\end{array}$ & 79.06 \\
\hline
\end{tabular}

As we can observe from the results of Table 1, structural components represent $80.9 \%$ of total variance of changes. KMO and Bartlet tests both confirm the validity of hypothesis. In our survey, Warm relationships (38.6), strong working relationship(24.7), facilitating structure(18.3) and Communication (27.8) are the most important components associated with structural variable.

In addition, relational capital is the second most important factor in our analysis where six components of this survey decribe $79.9 \%$ of total variance of changes. This factor includes Mutual trust relationships (30.7), Cooperation as a rule (18.9), existance of team work (23.2), accepting criticisim (18.6), Commitment to organization's interest (18.2), Being a member of family organization (19.6). 
The third factor, congnitive capital is the third important variable in our survey and it describes $71.64 \%$ of total variance of changes. In this category, existence of common objectives (43.7), and cooperation based on common interest (24.8) are important factors of our survey.

In summary, knowledge creation incorporates four components and represents $79.06 \%$ of total variance of changes. This item also includes four componets including Creating new opportunities by technology (12.3), Creating new technologies (26.8), Differenation between various technologies (26.2), Learning from technology (24.1).

Table 2 summarizes details of testing various variables using t-student test.

Table 2

Weight factors and t-strudent values of research variables and their components

\begin{tabular}{|c|c|c|c|}
\hline Variable & Component & t-student & Weight factor \\
\hline \multirow{6}{*}{ Structural } & Warm personal relations & 23.67 & 0.35 \\
\hline & Good working relationships & 12.13 & 0.82 \\
\hline & Facilitating communication structure & 9.34 & 0.94 \\
\hline & A one-way communications strategy & 12.45 & 0.75 \\
\hline & A two-way communications strategy & 13.64 & 0.64 \\
\hline & Quality of information & 8.85 & 0.71 \\
\hline \multirow{7}{*}{ Relational } & Relationships based on honesty and mutual trust & 9.54 & 0.75 \\
\hline & Collaboration as an imperative & 10.10 & 0.86 \\
\hline & Existance of team-work & 4.76 & 0.41 \\
\hline & Accepting critisim & 11.09 & 0.75 \\
\hline & Commitment to objectives & 9.23 & 0.68 \\
\hline & Preferring organization's interests & 6.87 & 0.64 \\
\hline & Member of a joint family & 10.24 & 0.81 \\
\hline \multirow[t]{2}{*}{ Cognitive } & Having common interests and objectives & 4.16 & 0.27 \\
\hline & Cooperation based on mutual understanding parables & 10.35 & 0.91 \\
\hline \multirow{4}{*}{$\begin{array}{l}\text { Creating } \\
\text { Knowledge }\end{array}$} & Create new business opportunities by technology & 7.54 & 0.70 \\
\hline & Creating new technologies & 10.75 & 0.85 \\
\hline & Distinguished technoqlogy from other ones & 9.32 & 0.73 \\
\hline & Learning from projects & 10.19 & 0.82 \\
\hline
\end{tabular}

In summary, the impacts of all three factors have been confirmed with structural capital with the coefficient of 0.76 , relational capital with 0.45 and cognitive with 0.39 .

\section{Conclusion}

Knowledge has been a precious asset in the new millennium and it is getting more important to learn the effects of different parameters influencing creation of knowledge. In this paper, we have presented an empirical study to investigate the effects of various parameters on knowledge creation in petrochemical industry. The results of our survey have shown that human capital components including structural, relational and cognitive significantly impact knowledge creation. Table 3 shows the summary of testing three hypotheses of this survey,

Table 3

The results of testing three hypotheses of the proposed study

\begin{tabular}{lcc}
\hline Hypothesis & t-value & Result of testing hypothesis \\
\hline Structural capital influence positively on knowledge creation. & 3.37 & Confirmed \\
Relational capital influence positively on knowledge creation. & 3.71 & Confirmed \\
Cognitive capital influence positively on knowledge creation. & 4.32 & Confirmed \\
\hline
\end{tabular}




\section{Acknowledgment}

The authors would like to thank the experts from petrochemical industry for their cooperation in accomplishing this survey. We are also grateful for constructive comments on earlier version of this paper.

\section{References}

Boisot, M. (1995). Information space: A framework for learning in organizations, institutions and culture. Cengage Learning Business Pr.

Bontis, N. (1999). Managing organisational knowledge by diagnosing intellectual capital: framing and advancing the state of the field. International Journal of Technology Management, 18(5), 433462.

Burt, R. S. (1995). Structural holes: The social structure of competition. Harvard University Press.

Carey, S., \& Lawson, B. (2011). Governance and social capital formation in buyer-supplier relationships. Journal of Manufacturing Technology Management,22(2), 152-170.

Chen, S.P., \& Wu, W.Y. (2010). A systematic procedure to evaluate an automobile manufacturerdistributor partnership. European Journal of Operational Research, 205(3), 687-698.

Chen, J., Zhu, Z., \& Xie, H. Y. (2004). Measuring intellectual capital: a new model and empirical study. Journal of Intellectual capital, 5(1), 195-212.

Cicourel, A. V. (1973). Cognitive sociology Penguin Books. Harmondsworth, UK.

Coleman, J. S. (1994). Foundations of social theory. Belknap Press.

Haghighat, F. (2008). The impact of information technology on coordination mechanisms of supply chain. World Applied Sciences Journal, 3(2), 74-81.

Hansen, M. T. (1999). The search-transfer problem: The role of weak ties in sharing knowledge across organization subunits. Administrative science quarterly, 44(1), 82-111.

Kogut, B., \& Zander, U. (1996). What firms do? Coordination, identity, and learning. Organization science, 7(5), 502-518.

Lévy Mangin, J. P., Koplyay, T., \& Calmès, C. (2008). The Moderator Effect of Communication in Marketing Channels of Distribution; The Case of Car's Industry in Canada. International Advances in Economic Research, 14(1), 48-64.

Mohr, J., \& Nevin, J. R. (1990). Communication strategies in marketing channels: A theoretical perspective. The Journal of Marketing, 36-51.

Nonaka, I., \& Takeuchi, H. (1995). The knowledge-creating company: How Japanese companies create the dynamics of innovation. Oxford University Press, USA.

Nahapiet, J., \& Ghoshal, S. (1998). Social capital, intellectual capital, and the organizational advantage. Academy of management review, 242-266.

Orr, J. E. (1990). Sharing knowledge, celebrating identity: Community memory in a service culture. Collective remembering, 169, 189.

Oliver, R. L., \& Anderson, E. (1995). Behavior-and outcome-based sales control systems: evidence and consequences of pure-form and hybrid governance. The Journal of Personal Selling and Sales Management, 1-15.

Prahinski, C., \& Benton, W. C. (2004). Supplier evaluations: communication strategies to improve supplier performance. Journal of Operations Management,22(1), 39-62.

Starbuck, W. H. (1992). Learning by knowledge-intensive firm. Journal of management Studies, 29(6), 713-740.

Wood, C., \& Bolloju, N. (2004). Supporting knowledge management in organizations with conversational technologies: Discussion forums, weblogs, and wikis. Journal of Database Management, 16(2), 1-8.

Wood, L., Giles-Corti, B., \& Bulsara, M. (2012). Streets Apart: Does Social Capital Vary with Neighbourhood Design?. Urban Studies Research, 2012. 
884

Zander, U., \& Kogut, B. (1995). Knowledge and the speed of the transfer and imitation of organizational capabilities: An empirical test. Organization science,6(1), 76-92. 